\title{
Skreddersydd medisin eller narsissomikk?
}

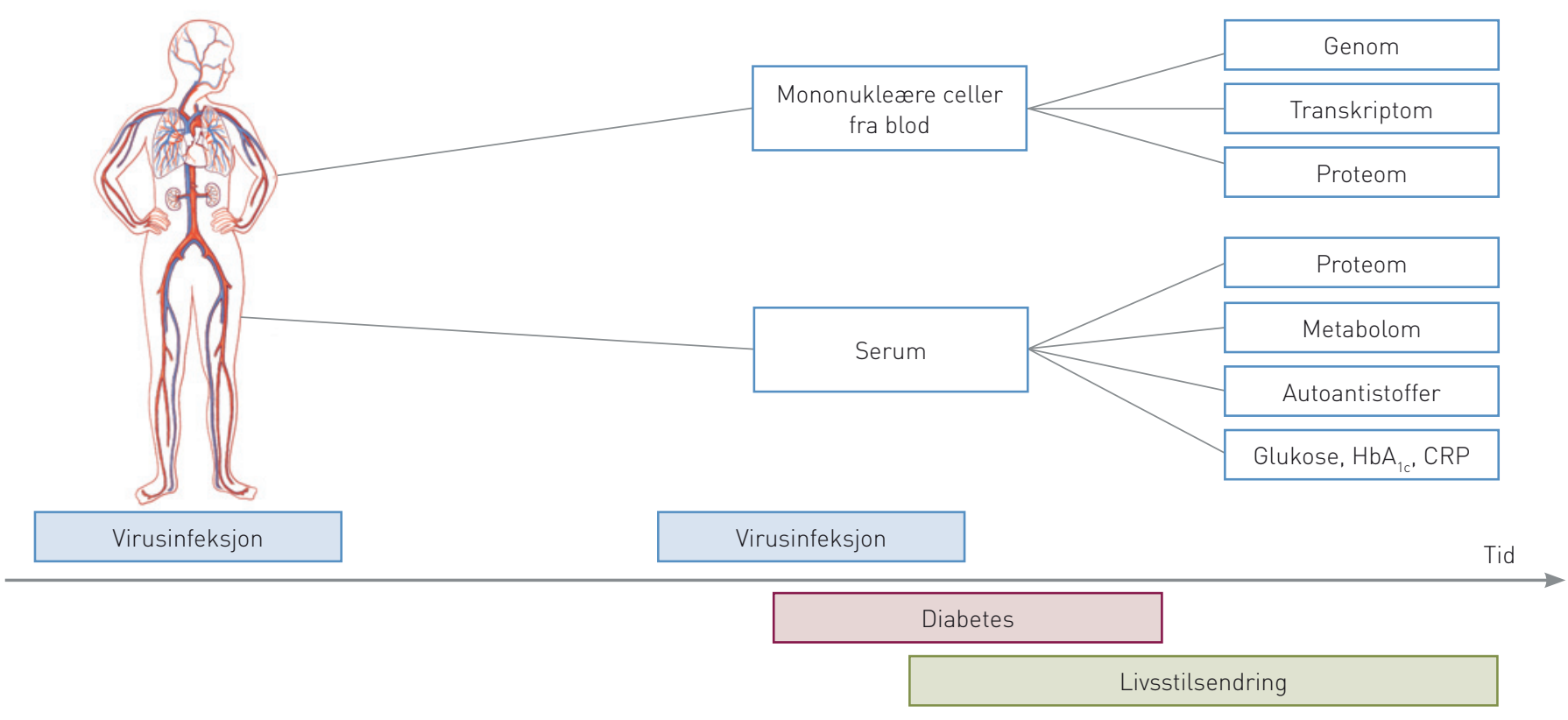

Figur 1 Strategien som Chen og medarbeidere brukte i jakten på en personlig og total molekylprofil. Til høyre er vist de analysene som ble gjort, nederst de viktigste hendelsene i studieperioden, som varte nesten to år

Snart kan man innhente ekstremt detaljert molekylær informasjon om pågående sykdomsprosesser og risiko for fremtidig sykdom. En artikkel i tidsskriftet Cell bærer bud om hva vi har i vente (1). Og man kan først som sist lære seg noen nyord som vil fortsette å prege biomedisinen i det 21. århundre: genomikk, transkriptomikk, proteomikk og metabolomikk.

Den uselvstendige orddelen -omikk (-omics på engelsk) refererer til en analyse innen biologien. Det relaterte suffikset -om, slik det brukes innen molekylærbiologien, indikerer en form for totalitet og forteller hva som analyseres. Innen medisinen ble ordet genom (alle genene i en organisme) definert i en tysk artikkel i 1920 og ble dermed et av de første -omene innen medisinen. Mange -omer er senere introdusert som nyttige begreper, spesielt innen bioinformatikken og molekylærbiologien, f.eks. proteom, som er blitt en vanlig betegnelse på alle uttrykte proteiner i en celle eller organisme under gitte betingelser. Proteomikk vil dermed bety storskalaanalyser av alle uttrykte proteiner i en celletype, et organ eller en undersøkt kroppsvæske på tidspunktet for undersøkelsen. Et annet eksempel er funksjonell genomikk, der målet er å identifisere funksjonen til så mange gener som mulig ved å kombinere ulike teknikker som transkriptomikk og proteomikk.

I studien i Cell integreres dybdesekvenseringsdata med repeterte prøver over en 14-månedersperiode der det er analysert millioner av gentranskripter, proteiner, metabolitter og autoantistoffer - alt i ett og samme individ (1). Studiens sisteforfatter var eneste forsøksobjekt! Med utgangspunkt i genetiske risikovarianter og sykdomsmutasjoner følges endringer i de ulike genproduktene $\mathrm{i}$ forbindelse med to interkurrente virusinfeksjoner samt utvikling og behandling av forsøksobjektets type 2-diabetes. Det vises et holdbart konsept for hvordan man kan bruke metoder som kartlegger og integrerer nesten hele arvematerialet og dets produkter for å følge pågående sykdomsprosesser, forstå de biologiske underliggende mekanismene og legge grunnlaget for individualisert behandling (fig 1). Artikkelen gir ikke bare helgenomisk informasjon om risiko for fremtidige sykdommer, noe vi allerede har hatt i noen år, men også et molekylært bilde av pågående sykdomsprosesser med et detaljeringsnivå som til nå savner sidestykke.

Tanken om individuell medisin er langt fra ny. Det har allid vært klinikerens siktemål å skreddersy behandlingen, helt fra Hippokrates' tradisjon til dagens translasjonelle medisin. Farmakogenetikken har vist hvordan moderne metoder kan frembringe klinisk individualisert behandling basert på funn i enkeltgener. Ett eksempel er at kunnskap om varianter i KCNJ11-genet hos pasienter med nyfødtdiabetes kan få terapeutiske konsekvenser, siden funn av aktiverende mutasjoner medfører at barna kan behandles med sulfonylureatabletter i stedet for insulininjeksjoner (2).

Med kartleggingen av det humane genom ble det satt store forhåpninger til individuell medisin. Det har utvilsomt vist seg at 
genomsekvensering har en nytteverdi (3), og eksomsekvensering for å finne enkeltgensykdommer i individer hvor man mistenker spontanmutasjoner eller mutasjoner med mendelsk arvemønster virker spesielt lovende (4). Samtidig genereres det så store datamengder at offentlige overoppsyn i USA (National Institutes of Health og Food and Drug Administration) har måttet utarbeide strategier som skal kvalitetssikre dataflommen (5).

Cell-artikkelen reiser noen interessante problemstillinger. Når utgangspunktet ikke lenger bare er hele genomet, men også alle dets mulige produkter i alle mulige kombinasjoner, kan man spørre om man klarer å lage fortolkningssystemer og kvalitetssikring som kan brukes fornuftig til å forutsi, forebygge og behandle sykdom. Videre kan man lure på om man, ut fra et stort utvalg av muligheter, valgte å vektlegge de biologiske prosessene som passet best, noe vi faller for fristelsen til å kalle selektomikk. I artikkelen ble det satt søkelys på funn av molekylære data i overensstemmelse med det naturlige forløp av to interkurrente infeksjoner samt utvikling av type 2-diabetes, mens endrede uttrykkingsnivåer av genprodukter som kunne knyttes til klinisk ikke-erkjente tilstander ikke ble kommentert (det ble f.eks. også funnet molekylære markører for Huntingtons sykdom). Andre problemstillinger kan knyttes til om man virkelig reduserer pasientens (og legens) usikkerhet om man bruker disse metodene $\mathrm{i}$ et forsøk på å identifisere risikofaktorer for sykdom. Risikostratifisering har vært vellykket i bl.a. kardiologien. Men kan bruk av disse metodene gi så detaljert kunnskap om pasientens ulike risikoprofiler at det oppstår etiske dilemmaer? Hva gjør man hvis man finner risikofaktorer hvor det er vanskelig eller umulig å intervenere eller hvor det er klinisk usikkerhet knyttet til hvor stor risikoen egentlig er? Da et dansk firma annonserte et tilbud om individrettede helgenomiske tester i norsk dagspresse, førte det til reaksjoner i både genetiske fagmiljøer og hos pasientene (6).

Arbeidet til Chen og medarbeidere er viktig fordi det illustrerer mulighetene som ligger foran oss. Studier av monogene sykdommer uten -omikktilnærming har gitt klinisk nyttig informasjon for den enkelte pasient (2), og vi tror den aktuelle tilnærmingsmåten kan være interessant også når det gjelder storskalaanalyser i utvalgte materialer, som familier med monogen sykdom eller kreft. Etter vårt syn er likevel arbeidet viktig først og fremst for å berede grunnen for fremtidig skreddersydd diagnostikk og behandling. Flere og flere sykdomsgener blir nå funnet ved hjelp av genomikk (dybdesekvensering). Signaturer basert på genomikk, transkriptomikk, proteomikk og metabolomikk gir allerede viktig informasjon om aktiverte signalveier som kan angripes terapeutisk (5).
Gudinnen Nemesis lokket den vakre jegeren Narkissos til å studere sitt eget speilbilde fordi hun så hans hovmod og arroganse. Han ble så forelsket $\mathrm{i}$ sitt eget bilde at det endte i døden. Noen har stilt spørsmål om artikkelen av Chen og medarbeidere mest er et eksempel på narsissomikk, altså et navlebeskuende studium av egne molekylære data (7). Vi får håpe at de nye metodene etter hvert kommer pasientene til gode og ikke blir et eksempel på vitenskapelig hybris i form av spektakulær og overmodig publisering.

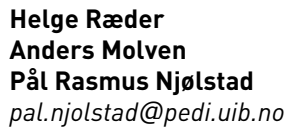

Helge Ræder (f. 1972) er spesialist i pediatri, overlege ved Barneklinikken, Haukeland universitetssykehus, og postdoktor ved Institutt for klinisk medisin, Universitetet i Bergen.

Forfatter har fylt ut ICMJE-skjemaet og oppgir ingen interessekonflikter.

Anders Molven (f. 1960) er professor i molekylærpatologi ved Gades institutt, Universitetet i Bergen, og spesialingeniør ved Avdeling for patologi, Haukeland universitetssykehus.

Forfatter har fylt ut ICMJE-skjemaet og oppgir ingen interessekonflikter.

Pål Rasmus Njølstad (f. 1961) er spesialist i pediatri, professor ved Institutt for klinisk medisin, Universitetet i Bergen, overlege ved Barneklinikken, Haukeland universitetssykehus, og leder for K.G. Jebsen-senter for diabetesforskning.

Forfatter har fylt ut ICMJE-skjemaet og oppgir ingen interessekonflikter.

\section{Litteratur}

1. Chen R, Mias GI, Li-Pook-Than J et al. Personal omics profiling reveals dynamic molecular and medical phenotypes. Cell 2012; 148: 1293-307.

2. Pearson ER, Flechtner I, Njølstad PR et al. Switching from insulin to oral sulfonylureas in patients with diabetes due to Kir6.2 mutations. N Engl J Med 2006. 355: 467-77.

3. Lander ES. Initial impact of the sequencing of the human genome. Nature 2011; 470: 187-97.

4. Ng SB, Buckingham KJ, Lee $C$ et al. Exome sequencing identifies the cause of a mendelian disorder. Nat Genet 2010; 42: 30-5.

5. Hamburg MA, Collins FS. The path to personalized medicine. N Engl J Med 2010; 363: $301-4$.

6. Hansen A, Tvedten HM. Advarer foreldre mot gentesting av barn. Dagbladet 1.3.2012. www.dagbladet.no/2012/03/01/nyheter/innenriks/gener/dna/ forskning/20458022 (27.6.2012)

7. Dennis C. The rise of the «narciss-ome». Nature 16.3.2012. www.nature.com/ news/the-rise-of-the-narciss-ome-1.10240 (27.6.2012). 